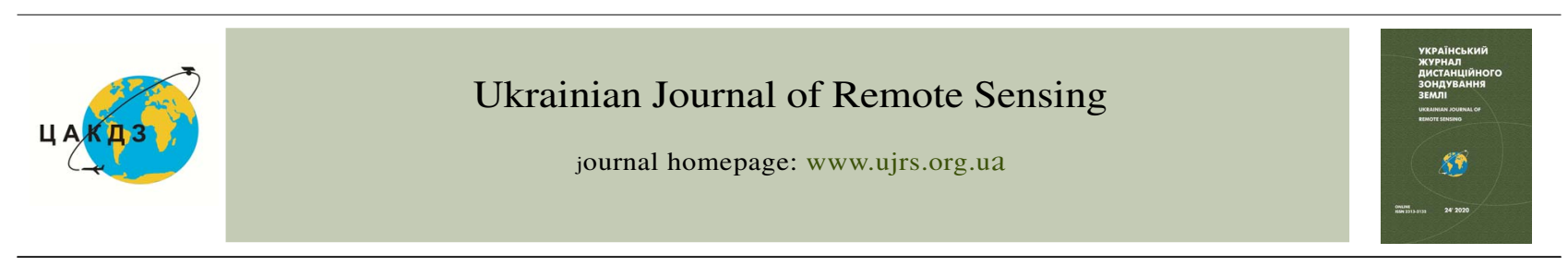

DOI: $10.36023 /$ ujrs.2020.24.165

UDC 528.852.3:004.932.1

\title{
Estimation of mutual subpixel shift between satellite images: software implementation
}

\author{
Sergey A. Stankevich ${ }^{1 *}$, Mikhail A. Popov ${ }^{1}$, Sergey V. Shklyar ${ }^{1}$, Konstantin Y. Sukhanov ${ }^{1}$, Artem A. Andreiev ${ }^{1}$, \\ Artur R. Lysenko ${ }^{1}$, Xing Kun ${ }^{2}$, Shixiang Cao ${ }^{2}$, Shi Yupan ${ }^{2}$, Sun Boya ${ }^{3}$ \\ ${ }^{1}$ Scientific Centre for Aerospace Research of the Earth, National Academy of Sciences of Ukraine, Kyiv, O. Gonchar st., 01054 Kyiv, Ukraine \\ ${ }^{2}$ Beijing Institute of Space Mechanics and Electricity, Beijing, China \\ ${ }^{3}$ CASICloud-Tech Co., Ltd. 303 3F 51 A Yongding Road Haidian District Beijing, 100048, China
}

The special-purpose software implementation for estimating the subpixel shift between satellite images using advanced computer technology is described in this paper. The automatic calculation of the mutual subpixel shift between a pair of digital satellite images by correlation algorithm is performed. The proposed implementation was tested on a statistically representative number of satellite images and reached acceptable accuracy in determining their subpixel shift values.

Keywords: satellite imagery, subpixel shift, software implementation

(C) S. A. Stankevich, M. A. Popov, S. V. Shklyar, K. Y. Sukhanov, A. A. Andreiev, A. R. Lysenko, X. Kun, S. Cao, S. Yupan, S. Boya. 2020

\section{Introduction}

The quality and detail of information extracted from satellite imagery are largely determined by the provided spatial resolution (Kwan, 2018). The spatial resolution enhancement under preserving other imaging specifications requires an increase in the number of photodetectors of sensing array, which leads to design complication and cost rise. In addition, the maximum number of photodetectors in the sensing array is strongly limited by the current level of microminiaturization in semiconductor manufacturing (Young, Driggers \& Jacobs, 2008). Subpixel image processing can mitigate such limitations. Subpixel processing involves (quasi)simultaneously acquired images of the same scene, which are shifted from one relative to the other into a fractional part of the pixel's geometric size, with the follow-up restoring the image values in all discrete pixel's parts (subpixels) (Fetisov, Kolesenkov, Babaev \& Fetisova, 2019).

A number of previous studies of the CASRE NAS of Ukraine have already been devoted to approaches and algorithms development for spatial resolution subpixel enhancement of the satellite images. The exact value of the mutual subpixel shift is a necessary input element of the algorithm for spatial resolution subpixel enhancement of the satellite images, also sometimes referred to as superresolution (Vandewalle, Süsstrunk \& Vetterli, 2003). A sufficiently complete overview of the known methods for the digital imagery superresolution is given in the (Boreman \& Stevenson, 1998) and (Milanfar, 2010) papers. Further, it is assumed that the mutual subpixel shift of two frame images displaced from each other by arbitrary pixel fractions, both horizontally and vertically, will be estimated (Popov, Stankevich

${ }^{*}$ E-mail: st@casre.kiev.ua
\& Shklyar, 2015; Stankevich, Shklyar \& Lubskyi, 2013; Stankevich, Shklyar \& Tyagur, 2013).

\section{General framework for subpixel shift estimation between satellite images}

Subpixel shift is estimated over two satellite images of equal size of the same scene, matched with each other with pixel precision. Since actual satellite images of the same scene have a less accurate co-registration, they must be prepared for processing. The sequence of this preparation and processing is described by the Fig. 1 flowchart.

Input satellite images (Image No 1 and Image No 2) are coregistered with pixel precision first. To do this, either the existing georeferencing data (Zhu et al., 2008) or the control points system that establishes a bijective alignment between two images (Dawn, Saxena \& Sharma, 2010) can be used. Next, the matched images are cropped (Crop Overlapping), ensuring that only the joint part (the overlap) of two images is saved (Hong \& Woo, 2014). After this, the preparation is completed and the subpixel shift determination (Subpixel Shift Calculation) can be executed. At the end of process, the results of the calculations are displayed (Result Output) to the user.

\section{Input image requirements}

Certain requirements must be placed on the input satellite images to ensure the accuracy of subpixel shift estimation. Primarily, there should be a unique approximation of the subpixel shift joint for the whole input images with some permissible accuracy. This condition imposes rather strong restrictions on the geometry of input images. Firstly, the consistency of scale over the field of image, and accordingly - 


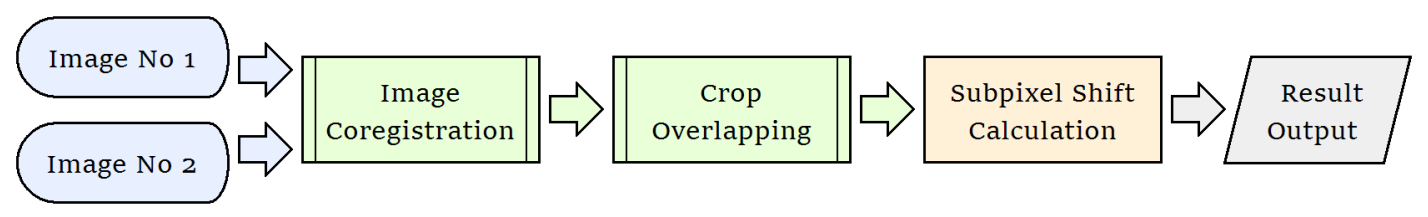

Fig. 1. Flowchart for subpixel shift estimation of two satellite images

the absence of oblique distortions. Secondly, the prohibition of angular misalignment of input images. Thirdly, the nonoccurrence of a constant-integer shift of input images. Fourthly, minimizing the higher-order non-linear distortions over the image field, such as optical disturbances, errors of imaging rasterization, etc. (Voronin, 2017).

The second important requirement is the stationarity of input images. There should be no significant changes between the images of the same scene during acquisition, for example, the presence of moving objects within the scene. In particular, the cloudiness in the image can make a significant distortion in the results of the shift estimation, so it is not recommended to use images with a large area of cloud cover. It is also not recommended to use pairs of input images obtained with a long time interval, during which significant changes in the scene could occur, such as inter-seasonal images (d'Angelo, 2013).

The third requirement is the use of images obtained in close (ideally - in the same) spectral bands. Significant radiometric differences between visible and near-infrared bands, and even more so - with mid-infrared, thermal infrared, microwave and radar ones, can lead to miscalculations or large errors in subpixel shift estimation (Ferraris, Dobigeon, Wei \& Chabert, 2018).

Since most of the essential calculations are done in the frequency domain and, in fact, based on inherently stochastical data, it is desirable to quantify the input images as the floatingpoint values. In addition, the unavoidable re-interpolation of images in the geometric transformations for co-registering (Moigne, Netanyahu \& Eastman, 2011) also forces the use of real value pixels to improve the radiometric and, accordingly, the statistical accuracy of the calculations performed. Therefore, it is recommended to convert the radiometric values of the input images into a floating-point format before processing. It is selfevident that all internal calculations must also be executed in double-precision floating-point value.

To ensure the most important requirement - the constancy of subpixel shift value over the field of input images, the most advanced or sophisticated co-registering techniques based on affine or even nonlinear spatial transforms may be necessary (Stankevich, 1994; Butyrin, 2015).

\section{Algorithm for determining the mutual integer pixels shift between two images}

A mutual integer pixels shift is needed to crop properly the overlap area of input images. To determine this shift, the mutual correlation function is calculated using the fast Fourier transform (FFT) and the sliding sum algorithm. It is noteworthy that the proposed algorithm is also suitable for images of different sizes (Reddy \& Chatterji, 1996).

For simplicity, the one-dimensional case of mutual correlation of two discrete datasets of different lengths is considered. If a longer set $\{\mathrm{yi}\}$ consists of $\mathrm{n}$ samples, and a short one $\{\mathrm{xi}\}$ consists of $\mathrm{m}$ samples, $\mathrm{m}<\mathrm{n}$, then for the $\mathrm{k}$ samples shift the rk correlation value will be:

$$
r_{k}=\frac{\sum_{i=1}^{m}\left(x_{i}-\bar{x}\right) \cdot\left(y_{i+k}-\bar{y}_{k}\right)}{\sqrt{\sum_{u=1}^{m}\left(x_{i}-\bar{x}\right)^{2} \sum_{u=1}^{m}\left(y_{i+k}-\bar{y}_{k}\right)^{2}}}
$$

where is a short set mean, and is a long set mean for m samples.

The numerator in (1) is the covariance ck. Since the correlation value does not depend on means, the covariance can be written as:

$$
c_{k}=\sum_{i=1}^{m} x_{i} \cdot y_{i+k}-\sum_{i=1}^{m} x_{i} \cdot \sum_{i=1}^{m} y_{i+k}
$$

In equation (2) the sum of the short set in the subtracted product term can be calculated in advance; the moving total algorithm can be used to calculate quickly the partial sum of a long set. It is obvious if the length of the short set is increased up to the length of the long one, assigning zeros to additional samples, then the equation (2) expression will not change, just the superior limit of the sum will be not $m$, but $n$. To calculate the $\sum_{i=1}^{m} x_{i} \cdot y_{i+k}$ value in equation (2), the FFT can be used.

The denominator in equation (1) is the root of the product of the variances. As with the case of covariance calculation, a short set variance can be calculated in advance, and for the long set variance bounded by the short set's window, the moving total algorithm will be applied for quick calculating.

The described method for quick calculating of correlations between different lengths datasets, one of which is much smaller than the other, is also applicable for a two-dimensional case - for the mutual shift of the two images determining.

\section{Correlation-based algorithm for determining the subpixel shift between two images}

In determining the mutual subpixel shift between two images of the same scene, the second image is considered as a parallel transfer from the first one. The task is to determine the vector of this parallel transfer.

The general algorithm for determining the subpixel shift between images is based on the following assumptions:

1) The true shift value corresponds to the maximum correlation between the input images;

2) Processing is performed in the frequency domain to reduce the computational burden;

3) Suppression of the high-frequency component is used to interpolate a discrete image.

The input data are two $Y_{1}$ and $Y_{2}$ images of $m \times n$ dimension at $(x, y)$ points, $x=0,1, \ldots, m-1, y=0,1, \ldots, n-1$. The pixel size is selected as a linear unit.

Discrete Fourier transform (DFT) is computed by the following equation:

$$
\hat{Y}(\theta, \vartheta)=\sum_{x=0}^{m-1} \sum_{y=0}^{n-1} Y_{k}(x, y) e^{-2 \pi i\left(\theta+\theta_{y}\right)}
$$


where $\mathrm{k}=1$ or $\mathrm{k}=2$ under $\theta=\ldots,-\frac{2}{m},-\frac{1}{m}, 0, \frac{1}{m}, \frac{2}{m}, \ldots$ and $\vartheta=\ldots,-\frac{2}{n},-\frac{1}{n}, 0, \frac{1}{n}, \frac{2}{n}, \ldots \hat{Y_{k}}(\theta, \vartheta)$ values will be considered for $|\theta|<\frac{1}{2},|\vartheta|<\frac{1}{2}$ only.

The influence of the low-frequency image component is reduced by multiplying the Fourier transform result by the $\omega(\theta)$ $\omega(\vartheta)$ function:

$$
\hat{F}_{k}(\theta, \vartheta)=\hat{Y}_{k}(\theta, \vartheta) \omega(\theta) \omega(\vartheta)
$$

where $\omega(\theta)=1$ under $-\frac{1}{4} \leq \theta \leq \frac{1}{4} ; \omega(\theta)=2-4|\theta|$ under $\frac{1}{4} \leq|\theta| \leq \frac{1}{4} ; \omega(\theta)=0$ under $|\theta| \geq \frac{1}{2}$.

The corresponding transform in spatial domain is the image interpolation by convolution with the const $\cdot\left(\cos \frac{\pi x}{2}-\cos \pi x\right)\left(\cos \frac{\pi y}{2}-\cos \pi y\right)$ function. In fact, this transform is not an exact interpolation because it changes the function values at the points where the function is defined. In order to ensure that the function defined values do not change, it is recommended to take $\omega(\theta)=1$ under $-\frac{1}{3} \leq \theta \leq \frac{1}{3}$; $\omega(\theta)=2-3|\theta|$ under $\frac{1}{3} \leq|\theta| \leq \frac{2}{3} ; \omega(\theta)=0$ under $|\theta| \geq \frac{2}{3}$.

As a result of the parallel transfer of the $Y_{1}(x, y)$ image onto $(\Delta x, \Delta y)$, that is $Y_{2}(x, y)=Y_{1}(x+\Delta x, y+\Delta y)$, its Fourier transform changes as follows:

$$
\hat{Y}_{2}(\theta, \vartheta)=\hat{Y}_{1}(\theta, \vartheta) e^{2 \pi i(\theta x+\vartheta \& y)}
$$

while the pixels that are on the image edge are ignored. In fact, Fourier transform, defined by equation (3), corresponds to a convolved image shift: the image part that is at the edge is transferred to the opposite edge.

To calculate the correlation between the images, the Parseval equation is used: if $\hat{Y}_{k}(\theta, \vartheta)$ is the Fourier transform of the $Y_{k}(x, y)$ function defined for $0 \leq x \leq m, 0 \leq y \leq n$, that is $\hat{Y}_{k}(\theta, \vartheta)=\int_{0}^{m} \int_{0}^{n} Y_{k}(x, y) e^{-2 \pi i(t+\theta+\theta y)} d x d y$, then

$$
\int_{0}^{m} \int_{0}^{m} Y_{1}(x, y) Y_{2}(x, y) d x d y=\frac{1}{m \cdot n} \sum_{\theta=\ldots,-\frac{1}{m}, 0, \frac{1}{m}, \ldots, \cdots} \sum_{\vartheta=\ldots, \frac{1}{n}, 0, \frac{1}{n}, \ldots} \hat{Y}_{1}(\theta, \vartheta) \hat{Y}_{2}(\theta, \vartheta)
$$

The Fourier transform of the second image shifted by after suppressing the high-frequency component will be

$$
\hat{F}_{2}^{(\Delta x, \Delta y)}(\theta, \vartheta)=\hat{F}_{2}(\theta, \vartheta) e^{2 \pi i(\theta x x+\vartheta \Delta y)} .
$$

The objective function is defined as

$$
\begin{aligned}
& Q(\Delta x, \Delta y)=\sum_{\theta=\ldots, \frac{1}{m}, 0, \frac{1}{m}, \ldots} \sum_{\theta, \ldots,-\frac{1}{n}, 0, \frac{1}{n}, \ldots, \ldots} \hat{F}_{1}(\theta, \vartheta) \hat{F}_{2}^{(\Delta x, \Delta y)}(\theta, \vartheta)= \\
& =\sum_{k=-\lfloor m / 2\rfloor}^{\lfloor m / 2\rfloor=\lfloor n / 2\rfloor} \sum_{1}^{\lfloor n / 2\rfloor}\left(\frac{k}{m}, \frac{l}{n}\right) \hat{F}_{2}\left(\frac{k}{m}, \frac{l}{n}\right) \exp \left[2 \pi i\left(\frac{k \Delta x}{m}+\frac{l \Delta y}{n}\right)\right]
\end{aligned}
$$

In case when an image shift of more than one pixel, the overall shift is decomposed as $\Delta x=\Delta x_{0}+\Delta x_{1}$ and $\Delta y=\Delta y_{0}+\Delta y_{1}$, where $\left(\Delta x_{0}, \Delta y_{0}\right)$ is the integer pixels shift. Then

$$
\begin{aligned}
& Q(\Delta x, \Delta y)=\sum_{k=-\lfloor m / 2\rfloor}^{\lfloor(m-1) / 2\rfloor} \sum_{l=-[n / 2\rfloor}^{\lfloor n-1 / 2\rfloor} \hat{F}_{1}\left(\frac{k}{m}, \frac{l}{n}\right) \hat{F}_{2}\left(\frac{k}{m}, \frac{l}{n}\right) \exp \\
& \exp \left[2 \pi i\left(\frac{k \Delta x_{0}}{m}+\frac{l \Delta y_{0}}{n}\right)\right] \exp \left[2 \pi i\left(\frac{k \Delta x_{1}}{m}+\frac{l \Delta y_{1}}{n}\right)\right]
\end{aligned}
$$

and for fixed $\Delta x_{1}$ and $\Delta y_{1}$ the function $Q\left(\Delta x_{0}+\Delta x_{1},\left(\Delta y_{0}+\Delta \mathrm{y}_{1}\right)\right.$ values are obtained by the inverse discrete Fourier transform of the

$$
\hat{F}_{2}\left(\frac{k}{m}, \frac{l}{n}\right) \hat{F}_{2}\left(\frac{k}{m}, \frac{l}{n}\right) \exp \left[2 \pi i\left(\frac{k \Delta x_{1}}{m}+\frac{l \Delta y_{1}}{n}\right)\right]
$$

array, where $k=0,1, \ldots,\left\lfloor\frac{m-1}{2}\right\rfloor,-\left\lfloor\frac{m}{2}\right\rfloor, \ldots,-1, \quad l=0,1, \ldots, \quad$. $\left\lfloor\frac{n-1}{2}\right\rfloor,-\left\lfloor\frac{n}{2}\right\rfloor, \ldots,-1$

A complete algorithm includes the following steps:

1) Preparing for the $Q(\Delta x, \Delta y)$ function calculation. In this case, the $\hat{F}_{1}(\theta, \vartheta) \hat{F}_{2}(\theta, \vartheta)$ is calculated under $\theta=\frac{k}{m}, k=-\left\lfloor\frac{m}{2}\right\rfloor, \ldots,\left\lfloor\frac{m-1}{2}\right\rfloor, \quad \vartheta=\frac{l}{n}, l=-\left\lfloor\frac{n}{2}\right\rfloor, \ldots,\left\lfloor\frac{n-1}{2}\right\rfloor$, and the necessary auxiliary arrays are filled;

2) Finding the $Q(\Delta x, \Delta y)$ maximum by $\Delta x_{1}=0, \frac{1}{16}, \ldots, \frac{15}{16}$ and $\Delta y_{1}=0, \frac{1}{16}, \ldots, \frac{15}{16}$ enumerating, and for each $(\Delta x, \Delta y)$ pair the $Q\left(\Delta x_{0}+\Delta x_{1}, \Delta y_{0}+\Delta y_{1}\right)$ is calculated simultaneously for all $\Delta x_{0}=\left\lfloor\frac{m}{2}\right\rfloor, 1-\left\lfloor\frac{m}{2}\right\rfloor, . .\left\lfloor\frac{m-1}{2}\right\rfloor, \Delta y_{0}=-\left\lfloor\frac{n}{2}\right\rfloor, 1-\left\lfloor\frac{n}{2}\right\rfloor, \ldots,\left\lfloor\frac{n-1}{2}\right\rfloor ;$ if any coordinate shift exceeds the pixel size, then the image must be cropped and step 1) must be repeated;

3) Numerical maximization of the $Q(\Delta x, \Delta y)$ function: the $\left(\Delta x_{0}+\Delta x_{1}, \Delta y_{0}+\Delta y_{1}\right)$ point is selected as the starting point, where all values of the $\Delta x_{0}+\Delta x_{1}, \Delta y_{0}+\Delta y_{1}$ variables are such that with them the maximum is reached in step 2 .

\section{Software for estimation of mutual subpixel shift between satellite images}

The software for automatic estimation of mutual subpixel shift between a pair of digital satellite images was developed. This software operates on a personal graphic workstation running by the 64-bit Microsoft Windows operating system and has a graphical user interface (GUI), which is shown in Fig. 2.

The software includes the following functional subsystems: input/output, computing, and control (Aydin, 2015). The developed software processes the satellite image fragments of the same pixel size, subpixel-shifted relative to each other. Processed images should be in the TIFF/GeoTIFF file format -single-band uncompressed 8,16 or 32 bits per pixel. 


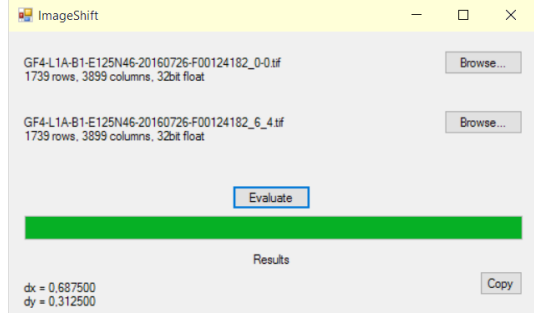

Fig. 2. The graphical interface of the software for estimation of mutual subpixel shift between satellite images

The developed software is quite productive and is capable of processing actual satellite images of 10-20 megapixels size and more.

\section{Developed software test results}

Testing and accuracy assessment of the developed software were carried out experimentally. The 30 pairs of test satellite images were generated for the experiment. All of them were artificially subpixelshifted the second relative to the first one. Reduced fragments of some used test images are shown in the Fig. 3.
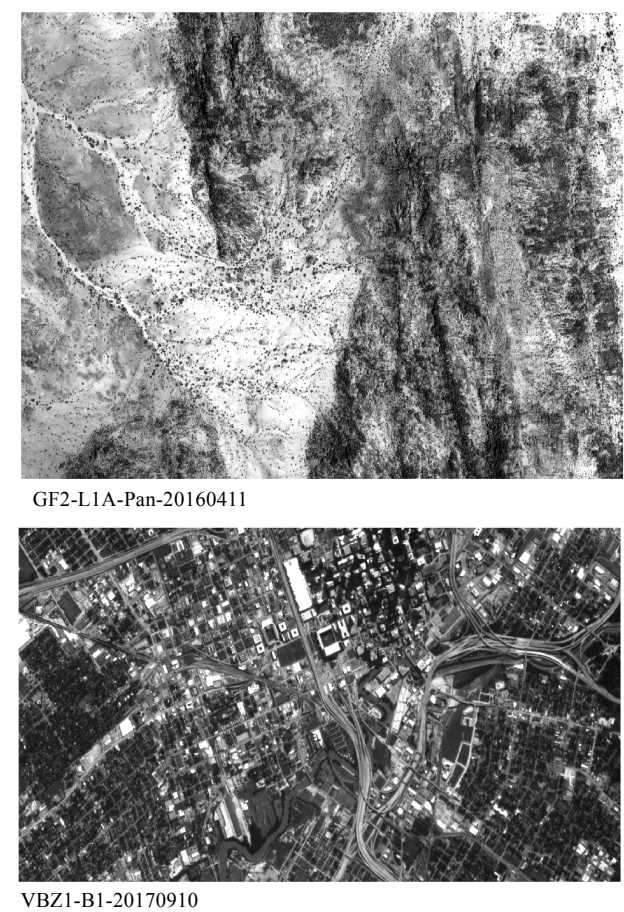

Fig. 3. Some test satellite images used to evaluate developed software
Processing time depends on the input image size and is equal up to a few seconds. Table 1 contains the values of set-pointed and estimated by the developed software subpixel shifts between pairs of test satellite images.

The mean absolute error in the subpixel shift estimating for all test satellite images was 0.037 . The processing time for a pair of images each $4000 \times 5000$ pixels size on a dual-core workstation does not exceed 4 minutes.

\section{Conclusions}

Algorithms and software for automatic estimation of mutual subpixel shift between satellite images are developed. The software implements a correlation estimating of the subpixel shift between two images within the frequency domain.

The developed software provides a quite acceptable accuracy in determining the subpixel shift value: the mean absolute error of 0.037 pixel is demonstrated. Also, this software has sufficient performance.

It is worth focusing the future research on optimizing the developed algorithms to reduce computational burden under the achieved accuracy preservation. In the long run, the described software is planned to be integrated into a complete software system for superresolution of input satellite image sets.

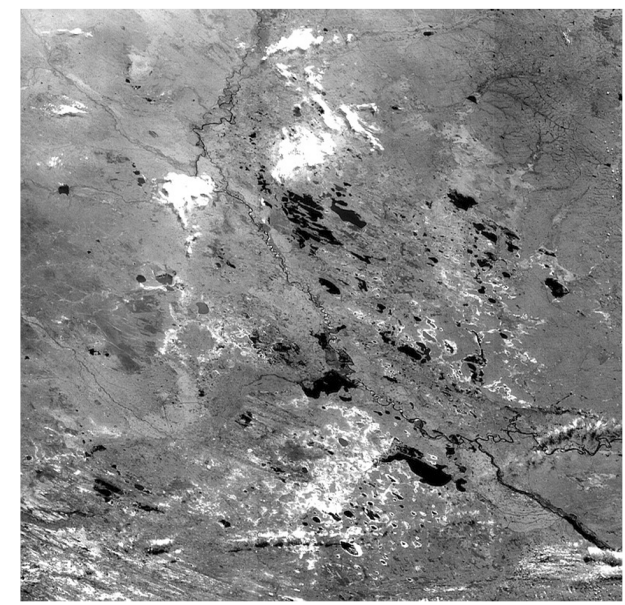

GF4-L1A-PMS-20160726

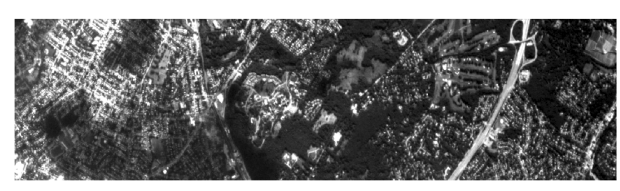

VBZ1-B3-20170720

Table 1

Subpixel shifts between test satellite images estimation results using developed software

\begin{tabular}{llll}
\hline Satel lite im ag e & $\begin{array}{l}\text { Imag e size, } \\
\text { pixels }\end{array}$ & $\begin{array}{l}\text { Set-poin t } \\
\text { subpixel shift }\end{array}$ & $\begin{array}{l}\text { Estimated } \\
\text { subp ixel shift }\end{array}$ \\
\hline GF2-L1 A-Pan- 20160411 & $2999 \times 1999$ & 0.55 & 0.56 \\
& & 0.35 & 0.34 \\
GF4-L1 A-PMS-20160726 & $1999 \times 999$ & 0.2 & 0.18 \\
& & 0.6 & 0.63 \\
VBZ1-B1-20170910 & $3286 \times 1662$ & 0.4 & 0.35 \\
& & 0.4 & 0.38 \\
VBZ1-B3-20170720 & $3386 \times 780$ & 0.8 & 0.75 \\
S2A-B8-20160617 & & 0.3 & 0.28 \\
& $3999 \times 2999$ & 0.75 & 0.8 \\
& & 0.45 & 0.44 \\
\hline
\end{tabular}




\section{References}

Aydin, S. (2015). Software competences of geomatic engineering. International Journal of Geosciences, 6 (12), 62118.

Boreman, S. \& Stevenson, R. (1998). Spatial resolution enhancement of low-resolution image sequences: A comprehensive review with directions for future research. Laboratory for Image and Signal Analysis (LISA) Technical Report. Notre Dame: University of Notre Dame.

Butyrin, S. A. (2015). A method for transformation of the space photos obtained at the distributed scanning optoelectronic observations. Bulletin of Samara Scientific Center of the RAS, 17 (6), 702-706. (in Russian).

d'Angelo, P. (2013). Automatic orientation of large multitemporal satellite image blocks. Proceedings of International Symposium on Satellite Mapping Technology and Application (ISSMTA2013), 1-7. Nanjing: ISPRS.

Dawn, S., Saxena, V. \& Sharma, B. (2010). Remote sensing image registration techniques: A survey. Proceedings of the 4th International Conference on Image and Signal Processing, (ICISP 2010), 103112. Québec: Springer.

Ferraris, V., Dobigeon, N., Wei, Q. \& Chabert, M. (2018). Detecting changes between optical images of different spatial and spectral resolutions: A fusion-based approach. IEEE Transactions on Geoscience and Remote Sensing, 56 (3), 1566-1578.

Fetisov, D. V., Kolesenkov, A. N., Babaev, S. I. \& Fetisova, T. A. (2019). Development of a model for subpixel processing of aerospace images during remote sensing of the Earth. Nauchnyy vestnik NGTU, 2 (75), 89-100. (in Russian).

Hong, A. N. \& Woo, D. M. (2014). Fast stereo matching of high resolution satellite images using a new tilting technique. Proceedings of the 2nd International Conference on Emerging Trends in Engineering and Technology (ICETET'2014), 91-95. London: IIE.

Kwan, C. (2018). Image resolution enhancement for remote sensing applications. Proceedings of the 2nd International Conference on Vision, Image and Signal Processing, 12. Las Vegas: ACM.
Milanfar, P. (Ed.). (2010). Super-Resolution Imaging. Boca Raton: CRC Press.

Moigne, J. L., Netanyahu, N. S. \& Eastman, R. D. (Eds). (2011). Image Registration for Remote Sensing. Cambridge: Cambridge University Press.

Popov, M. A., Stankevich, S. A. \& Shklyar, S. V. (2015). An algorithm for resolution enhancement of subpixel displaced images. Mathematical Machines and Systems, 1, 29-36. (in Russian).

Reddy, B. S. \& Chatterji, B. N. (1996). An FFT-based technique for translation, rotation, and scale-invariant image registration. IEEE Transactions on Image Processing, 5 (8), 1266-1271.

Stankevich, S. A. (1994). The models for segmented discrete images automatic matching. Proceedings of the 2nd All-Ukrainian International Conference on Signal/Image Processing and Pattern Recognition, 167-169. Kiev: Institute of Cybernetics NAS of Ukraine. (in Ukrainian).

Stankevich, S. A., Shklyar, S. V. \& Lubskyi, N. S. (2013). Aerial imaging spatial resolution enhancement based on subpixel image registration. Proceedings of Aviation Research Institute, 9 (16), 125-132. (in Ukrainian).

Stankevich, S. A., Shklyar, S. V. \& Tyagur, V. M. (2013). Satellite imagery resolution enhancement using subpixel frames acquisition. Journal of Information, Control and Management Systems, 11 (2), 135-144.

Vandewalle, P., Süsstrunk, S. \& Vetterli, M. (2003). Superresolution images reconstructed from aliased images. Proceedings of the SPIE, $5150,1398-1405$.

Voronin, E.G. (2017). On the displacements of the contours of the opticelectronic space images. Causes and evaluation of offsets. Geodeziya i kartografiya, 78 (5), 34-41. (in Russian).

Young, S. S., Driggers, R. G. \& Jacobs, E. L. (2008). Signal Processing and Performance Analysis for Imaging Systems. Norwood: Artech House.

Zhu, L., Erving, A., Koistinen, K., Nuikka, M., Junnilainen, H., Heiska, N. \& Haggrén, H. (2008). Georeferencing multi-temporal and multiscale imagery in photogrammetry. The International Archives of the Photogrammetry, Remote Sensing and Spatial Information Sciences, XXXVII (B5), 225-230.

\section{ПРОГРАМНА РЕАЛІЗАЦІЯ ОЦНКИ ВЗАСМНОГО СУБПІКСЕЛЬНОГО ЗСУВУ МІЖ СУПУТНИКОВИМИ ЗОБРАЖЕННЯМИ}

С. А. Станкевич, М. О. Попов, С. В. Шкляр, К. Ю. Суханов, А. А. Андреєв, А. Р. Лисенко, Сінь Кунь, Шисян Цяо, Ши Юйпань, Сунь Бойя У статті описано алгоритми і програмна реалізація з використанням сучасних комп'ютерних технологій спеціального програмного забезпечення для оцінки субпіксельного зсуву між супутниковими зображеннями. Для забезпечення заданої точності оцінки субпіксельного зміщення до початкових супутникових зображень пред'являються певні вимоги. Передусім, повинне існувати єдине наближення субпіксельного зсуву початкових зображень з деякою припустимою погрішністю. Друга важлива вимога - стаціонарність вхідних зображень. Третя вимога - використання зображень, отриманих у близьких спектральних діапазонах.

Увесь процес складається з трьох основних етапів: сполучення зображень, вирізування спільної піксельно сполученої частини та автоматичного розрахунку взаємного субпіксельного зсуву. Автоматичний розрахунок взаємного субпіксельного зсуву між двома цифровими супутниковими зображеннями виконується кореляційним методом. Окремо розглянуто алгоритм визначення цілопіксельного взаємного зсуву двох зображень за допомогою взаємної кореляції, що обчислюється швидким перетворенням Фур'є (БПФ) і способом ковзаючої суми, та алгоритм визначення субпіксельного зсуву двох зображень з використанням розрахунку кореляції у Фур'є-області.

Програмну реалізацію вказаних алгоритмів було виконано на алгоритмічній мові С з використанням відкритих програмних компонентів $\mathrm{i}$ бібліотек. Розроблене програмне забезпечення функціонує на персональній графічній робочій станції під управлінням 64-бітної операційної системи Microsoft Windows i має графічний інтерфейс користувача (GUI). Запропоновану програмну реалізацію було випробувано на статистично репрезентативній кількості реальних супутникових зображень. В результаті випробувань було продемонстровано цілком прийнятну (краще за 0.1 піксел) точність визначення значень їх субпіксельних зсувів.

Ключові слова: супутникові зображення, субпіксельний зсув, програмна реалізація

\section{ПРОГРАММНАЯ РЕАЛИЗАЦИЯ ОЦЕНКИ ВЗАИМНОГО СУБПИКСЕЛЬНОГО СДВИГА МЕЖДУ СПУТНИКОВЫМИ} ИЗОБРАЖЕНИЯМИ

С. А. Станкевич, М. А. Попов, С. В. Шкляр, К. Ю. Суханов, А. А. Андреев, А. Р. Лысенко, Синь Кунь, Шисян Цяо, Ши Юйпань, Сунь Бойя В статье описаны алгоритмы и программная реализация с использованием современных компьютерных технологий специального программного обеспечения для оценки субпиксельного сдвига между спутниковыми изображениями. Для обеспечения заданной точности оценки субпиксельного смещения к исходным спутниковым изображениям предъявляются определённые требования. Прежде всего, должно существовать единственное приближение субпиксельного смещения исходных изображений с некоторой допустимой погрешностью. Второе важное требование - стационарность исходных изображений. Третье требование - использование изображений, полученных в близких спектральных диапазонах.

Весь процесс состоит из трёх основных этапов: совмещения изображений, вырезания общей пиксельно совмещённой части и автоматического 
расчёта взаимного субпиксельного сдвига. Автоматический расчёт взаимного субпиксельного сдвига между двумя цифровыми спутниковыми изображениями выполняется корреляционным методом. Отдельно рассмотрены алгоритм определения целопиксельного взаимного смещения двух изображений при помощи взаимной корреляции, вычисляемой посредством быстрого преобразования Фурье (БПФ) и способом скользящей суммы, и алгоритм определения субпиксельного смещения двух изображений с использованием расчёта корреляции в Фурьеобласти.

Программная реализация указанных алгоритмов была выполнена на алгоритмическом языке С с использованием открытых программных компонентов и библиотек. Разработанное программное обеспечение функционирует на персональной графической рабочей станции под управлением 64-битной операционной системы Microsoft Windows и имеет графический интерфейс пользователя (GUI). Предложенная программная реализация была опробована на статистически репрезентативном количестве реальных спутниковых изображений и продемонстрировала вполне приемлемую точность (лучше 0,1 пиксела) определения значений их субпиксельных сдвигов.

Ключевые слова: спутниковые изображения, субпиксельный сдвиг, программная реализация

Рукопис статті отримано 25.02.2020 